ARAŞTIRMA / RESEARCH

\title{
Inhibition of mTOR protects against skeletal muscle and kidney injury following hindlimb ischemia-reperfusion in rats by regulating MEK1/ERK1/2 activity
}

mTOR'un inhibisyonu, MEK1/ERK1/2 etkinliğini düzenleyerek s1çanlarda arka bacak iskemi-reperfüzyonunun neden olduğu iskelet kası ve böbrek zedelenmesine karşı koruma sağlar

\author{
Çağla Akıncı-Uysal1D, Meryem Temiz-Reşitoğlu1D, Demet Sinem Güden1(D)

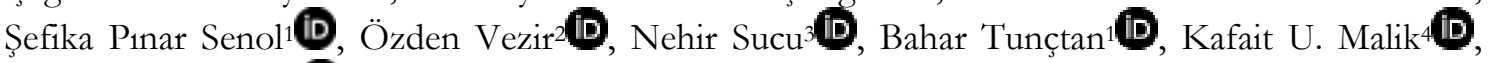 \\ Seyhan Sahan-Firat 10
}

${ }^{1}$ Mersin University, Faculty of Pharmacy, Department of Pharmacology, Mersin, Turkey;

${ }^{2}$ Mersin State Hospital, Department of Cardiovascular Surgery, Mersin, Turkey;

${ }^{3}$ Mersin University, Faculty of Medicine, Department of Cardiovascular Surgery, Mersin, Turkey

${ }^{4}$ University of Tennessee, Center for Health Sciences, College of Medicine, Department of Pharmacology, Memphis, TN, USA

\begin{abstract}
Purpose: We have previously demonstrated that activation of the mammalian target of rapamycin $(\mathrm{mTOR}) /$ inhibitory- $x \mathrm{~B}-\alpha /$ nuclear factor- $x \mathrm{~B}$ p65 signaling pathway mediates organ injuries through increased oxidative/nitrosative stress and inflammatory response in rat models of hind limb ischemia/reperfusion (HL I/R). Following up our previous findings regarding $\mathrm{I} / \mathrm{R}$ injury through mammalian target of rapamycin (mTOR), we aimed to focus on the possible interaction between mammalian target of rapamycin (mTOR and mitogenactivated protein kinase kinase (MEK)1/extracellular signal-regulated kinase (ERK) 1/2 pathway in hind limb ischemia/reperfusion (HL I/R) resulting in target and remote organ injuries in the present study.

Materials and Methods: Male Wistar rats were divided into four groups. HL I/R was induced by occluding with tourniquets of both hind limbs. Following $4 \mathrm{~h}$, the tourniquets were removed following reperfusion for $4 \mathrm{~h}$. After $4 \mathrm{~h}$ of reperfusion blood, kidney, and gastrocnemius muscle were collected.

Results: HL I/R caused an increase in phosphorylation and/or expression of $\mathrm{rpS6}$, MEK1, ERK1/2, tumor necrosis factor- $\alpha$, inducible nitric oxide synthase, gp91phox, p22phox, and nitrotyrosine as well as nitrite levels in

Öz

Amaç: Arka bacak iskemisi/reperfüzyonun (I/R) sıçan modellerinde, rapamisinin memelilerdeki hedefi (mTOR)/inhibitör- $x \mathrm{~B}-\alpha /$ nükleer faktör- $\varkappa \mathrm{B}$ p65 sinyal ileti yolu etkinliğinin, artan oksidatif/nitrozatif stres ve inflamatuvar yanıt yoluyla organ zedelenmelerine aracilık ettiğini daha önce göstermiştik. mTOR'un $\dot{I} / R$ zedelenmesine katkıda bulunduğuna ilișkin önceki bulgularımızı referans alarak, bu çalısmada arka bacak I/R'ye bağlı hedef ve uzak organ zedelenmelerinde mTOR ile MEK1/ERK1/2 yolu arasındaki olas1 etkileşime odaklanmayı amaçladık.

Gereç ve Yöntem: Erkek Wistar sıçanlar dört gruba ayrıldı. Arka bacak $\dot{I} / R$, her iki arka ekstremitelerine turnikeler uygulanarak iskemi oluşturuldu. İskemiden 4 saat sonra turnikeler açllarak 4 saat reperfüzyon uygulandi. 4 saatlik reperfüzyondan sonra kan, böbrek ve gastroknemius kası izole edildi.

Bulgular: Arka bacak $\mathrm{I} / \mathrm{R}$ uygulaması gastroknemius kasinda, böbrekte ve/veya serumda rpS6, MEK1, ERK1/2, tümör nekroz faktörü- $\alpha$, indüklenebilir nitrik oksit sentaz, gp91phox, p22phox ve nitrotirozinin fosforilasyonu ve/veya ekspresyonu ile birlikte nitrit düzeylerinde artışa neden oldu. Ayrıca, I/R uygulanan sıçanların dokularında nikotinamit adenin dinükleotit
\end{abstract}

Cukurova Medical Journal 2022;47(1):219-232. 
gastrocnemius muscle, kidney, and/or serum Additionally, nicotinamide adenine dinucleotide phosphate oxidase and myeloperoxidase levels were increased in the tissues of rats subjected to HL I/R. Rapamycin, the selective inhibitor of mTOR, abolished all the effects mentioned above caused by HL I/R in the rat's muscle and kidney.

Conclusion: These data suggest that activation of the MEK1/ERK1/2 pathway contributes to mTORmediated HL I/R-induced target and remote organ injury. Keywords:. mTOR, MEK1, ERK1/2, hind limb ischemia/reperfusion, oxidative/nitrosative stress, inflammation

\section{INTRODUCTION}

Hind limb ischemia/reperfusion (HL I/R) injury is a complex phenomenon often seen in clinical events, including surgery, trauma, or sepsis leading to functional disturbances. HL I/R injury is a condition that affects the prognosis of cases subjected to reconstructive and replantation surgeries, and reexploration ${ }^{1}$. It may occur after reintroducing oxygenated blood to ischemic tissues due to the generation of free oxygen radicals and activated neutrophils ${ }^{2}$. A large body of data indicates that the overproduction of reactive oxygen species (ROS) and proinflammatory molecules and the subsequent inflammatory response are among the most crucial underlying mechanisms of $\mathrm{HL} \mathrm{I/R} \mathrm{R}^{3}, 4$.

On the other hand, this injury is not only limited to organs affected directly by HL I/R but also distant organs. The frequent clinical problem in HL I/R is commonly seen in orthopedic, musculoskeletal reconstructive procedures, vascular surgeries, traumatic vascular injury, surgical repair of abdominal aortic aneurysm, and remote multisystem organ dysfunction $^{5-7}$. HL I/R is associated with a systemic inflammatory response and affects distant organs such as the liver, lung, kidney, and testis and their structure and function ${ }^{8-11}$.

The development of remote organ dysfunction was observed only following reperfusion, which implies that cellular mediators produced locally in the limb are responsible for mediating remote organ injury ${ }^{12}$, 13. However, intracellular mechanisms and the course of HL I/R injury are complex and multifaceted. Previously published data suggest that the HL I/R induced organ injuries could be mitigated by fosfat oksidaz ve miveloperoksidaz seviyeleri artt1. mTOR'un seçici inhibitörü olan rapamisin, sıçanlarda kas ve böbrek dokusunda $\dot{I} / R^{\prime}$ nin neden olduğu yukarıda bahsedilen tüm etkileri ortadan kaldırdı.

Sonuç: Bu veriler, MEK1/ERK1/2 yolunun etkinliğinin, mTOR'un aracilık ettiği arka bacak I/R'nin neden olduğu hedef ve uzak organ zedelenmesine katkıda bulunduğunu göstermektedir.

Anahtar kelimeler: mTOR, MEK1, ERK1/2, arka bacak iskemi/reperfüzyon, oksidatif/nitrozatif stres, inflamasyon

therapies aimed to decrease the oxidative stress and/or inflammatory response ${ }^{14}$.

Mammalian target of rapamycin (mTOR) is an evolutionary serine/threonine kinase involved in many fundamental cellular processes, including protein synthesis, migration, and proliferation in the eukaryotic cells. Dysregulated mTOR signaling leads to the progression of common diseases, characterized by ischemic injury ${ }^{15}$. Several studies have demonstrated the protective effects of mTOR activation during HL I/R; in contrast, other studies have reported destructive results. However, emerging evidence suggests that mTOR inhibition by rapamycin has protective effects on tissue and organ damage induced by HL I/R, especially on neuronal and cardiovascular tissues ${ }^{16-19}$. Notably, the roles of the mTOR in HL I/R injury have gotten much attention in recent years, and mTOR can also be considered as an important player against HL I/R injury ${ }^{20-22}$.

In our previous study, we showed for the first time that $\mathrm{mTOR}$ activates inhibitory- $x \mathrm{~B}(\mathrm{I} \varkappa \mathrm{B})-\alpha /$ nuclear factor $x \mathrm{~B} \quad(\mathrm{NF}-x \mathrm{~B}) \quad \mathrm{p} 65, \quad$ triggering oxidative/nitrosative stress and inflammation resulting in muscle and kidney injury in a murine model of $\mathrm{HL} I / \mathrm{R}^{23}$. In parallel with this, demonstration of mitogen-activated protein kinase kinase (MEK)1/extracellular signal-regulated kinase (ERK) $1 / 2$ activation also participates in oxidative/nitrosative stress and inflammatory response. These observations led us to hypothesize that the interaction between mTOR and MEK1/ERK1/2 activity in $I / R$ injury results in target and remote organ injuries. The present study was performed to test this hypothesis. 


\section{MATERIAL AND METHODS}

\section{Chemicals}

Rapamycin was purchased from Gold Biotechnology (St. Louis, MO, USA). Bovine serum albumin (BSA) and Bradford reagent were purchased from Sigma Chemical Co. (St. Louis, MO, USA). Myeloperoxidase (MPO) and nicotinamide adenine dinucleotide phosphate (NADPH) oxidase ELISA kits were obtained from Cloud-Clone Corp. (TX, USA) and MyBioSource (San Diego, CA, USA), respectively. Primary antibodies for rpS6 and p-rpS6 (Cell Signalling Technology, Danvers, MA, USA), MEK1, p-MEK1, ERK1/2, p-ERK1/2, tumor necrosis factor (TNF)- $\alpha$, p22phox, gp91phox, nitrotyrosine (Santa Cruz Biotechnology, TX, USA), inducible nitric oxide synthase (iNOS) (BD Transduction Lab., San Jose, CA, USA), and $\alpha$ sarcomeric actin and $\beta$-actin (Sigma Chemical Co, St. Louis, MO, USA) were obtained. Secondary antibodies (sheep anti-mouse IgG- and goat antirabbit IgG-horseradish peroxidase) from Abcam (Cambridge, UK) and ECL Prime Western Blotting Detection Reagents from Amersham Life Sciences (Cleveland, OH, USA) were also obtained.

\section{Animals}

Thirty-two adult male Wistar rats weighing 200-300 g were used in this study (Research Center of Experimental Animals, Mersin University, Mersin, Turkey). All procedures were carried out according to the National Institutes of Health Guide for the Care and Use of Laboratory Animals. They were kept on a 12:12 h light-dark cycle and fed standard rat chow before the experiments. The study was approved by the Mersin University Experimental Animals Local Ethics Committee.

\section{Experimental design}

Rats were separated into 4 groups: control $(\mathrm{n}=8), \mathrm{I} / \mathrm{R}$ $(\mathrm{n}=8)$, RAPA $(\mathrm{n}=8)$, and I/R+RAPA $(\mathrm{n}=8)$. As a result of the power analysis performed with $5 \%$ type 1 error and $80 \%$ power using the averages of NADPH oxidase activity in reference sources, it has been calculated that a minimum of 4 and a maximum of 6 animals can be studied in each group when the resource equality method is used. Since the mortality may be seen in the study, 8 rats has been used in each group. HL I/R model was induced as previously referred by Sucu et al. and Sari et $\mathrm{al}^{24,25}$. In I/R and
I/R+RAPA groups, HL I/R was achieved by applying rubber-band tourniquets on both hind limbs, proximal to trochanter major in all animals under ketamine $(90 \mathrm{mg} / \mathrm{kg}$, i.m.) / xylazine $(10 \mathrm{mg} / \mathrm{kg}$, i.m.) anesthesia. Following ischemia for $4 \mathrm{~h}$, the tourniquets were released, allowing reperfusion for 4 h. In the groups of the vehicle and I/R, rats were administrated saline ( $4 \mathrm{ml} / \mathrm{kg}$; i.p.), and in the groups of RAPA and I/R+RAPA; rats were injected with rapamycin $(1 \mathrm{mg} / \mathrm{kg}$, i.p.) $1 \mathrm{~h}$ before reperfusion. At the end of the experiments, rats were euthanized with ketamine/xylazine anesthesia, and blood, kidney, and gastrocnemius muscles were isolated. Serum was separated by centrifugation at $23,910 \mathrm{x}$ for $15 \mathrm{~min}$ at $4^{\circ} \mathrm{C}$, frozen, and stored at $-20^{\circ} \mathrm{C}$ till the time of analysis. Isolated tissues were quickly frozen and stored at $-80^{\circ} \mathrm{C}$. Frozen tissues were ground to a fine powder in liquid nitrogen and homogenated in 1-2 ml of an ice-cold $20 \mathrm{mM}$ HEPES buffer (pH:7.5). The homogenates were centrifuged at 23,910 $\mathrm{x} g$ for 10 min at $4^{\circ} \mathrm{C}$ and sonicated for $15 \mathrm{~s}$ on ice with $50 \mu \mathrm{l}$ ice-cold Tris $(50 \mathrm{mM}, \mathrm{pH} 8.0)$ and $\mathrm{KCl}(0.5 \mathrm{M})$. The lysates were then centrifuged at $23,910 \times \mathrm{g}$ for $15 \mathrm{~min}$ at $4^{\circ} \mathrm{C}$ and supernatants were collected, divided into aliquots and stored at $-80^{\circ} \mathrm{C}$ for evaluation of $\mathrm{rpS} 6$, MEK1, ERK1/2, TNF- $\alpha$, iNOS, p22phox, gp91phox, nitrotyrosine, $\alpha$-sarcomeric actin, and $\beta$-actin, protein expressions and/or activities in addition to MPO and NADPH oxidase activity. The amount of total protein in the supernatants was measured using the Bradford method.

\section{Western blot assay}

rpS6, MEK1, ERK1/2, TNF- $\alpha$, iNOS, p22phox, gp91phox , nitrotyrosine, and actin protein expressions and/or phosphorylations in muscle and kidney were performed according to the method described previously ${ }^{26-29}$. Equal amounts of protein $(90-100 \mu \mathrm{g})$ were subjected to $10 \%$ sodium dodecyl sulfatepolyacrylamide gel electrophoresis, and then separated proteins were transferred to the nitrocellulose membrane. The membranes were blocked with $5 \%$ non-fat dry milk in Tris-buffered saline (TBST) (mmol/l: Tris-HCl 25 [pH 7.4], NaCl 137, $\mathrm{KCl} \mathrm{27}$, and $0.05 \%$ Tween 20 ) at room temperature for $1 \mathrm{~h}$ and then probed with specific primary antibodies in TBST including 5\% BSA at 1:500-1:40000 dilutions overnight at $4{ }^{\circ} \mathrm{C}$ followed by incubation with secondary antibodies in TBST including $0.1 \% \mathrm{BSA}$ at 1:1.000 for $2 \mathrm{~h}$ at room temperature. The blots were detected with enhanced 
chemiluminescence by using ECL Prime Western blotting detection reagent. The density of the bands was analyzed using Image J software version 1.46r.

\section{Measurement of MPO, NADPH oxidase, and nitrite levels}

MPO and NADPH oxidase levels in the tissue samples were measured by ELISA kits as recommended by the manufacturer's protocol. Nitrite levels in sera and tissue homogenates were analyzed using the Griess reaction as the indicator of NOS-derived NO production ${ }^{30}$. Briefly, samples (25 $\mu \mathrm{l})$ were pipetted into plates, and an equal volume of Griess reagent ( $1 \%$ sulphanilamide and $0.1 \% \mathrm{~N}-1$ naphthyl ethylenediamine dihydrochloride in $2.5 \%$ phosphoric acid) was added to each well. After incubation at room temperature for $10 \mathrm{~min}$, absorbance was measured at $550 \mathrm{~nm}$ with a microplate reader. A standard curve was constructed according to known concentrations of sodium nitrite.

\section{Statistical analysis}

Quantitative data were presented as the means \pm standard error mean. GraphPad Prism 5.0
Version for Windows, GraphPad Software (San Diego, CA, USA) was applied in performing the statistical analyses. After evaluating the conformity of the data in the study to the normal distribution, statistical analyses between the groups were performed according to one-way analysis of variance (ANOVA) in all parameters. Statistically significance was accepted for $P$ values $<0.05$, differences among the groups were obtained using post hoc the StudentNewman-Keuls test in all parameters and they were considered statistically significant at $(P<0.05)$.

\section{RESULTS}

We examined rpS6 expression and phosphorylation to investigate mTOR activity in gastrocnemius muscle and kidney. HL I/R increased rpS6 phosphorylation without altering $\mathrm{rpS} 6$ expression in both tissues. The increase in $\mathrm{rpS} 6$ phosphorylation triggered by $\mathrm{I} / \mathrm{R}$ was reversed by rapamycin $(\mathrm{P}<0.05$; Fig. 1). In contrast, rapamycin alone did not affect the expression or phosphorylation of $\mathrm{rpS} 6$ in any of the tissues $(\mathrm{P}>0.05$; Fig. 1$)$.

B
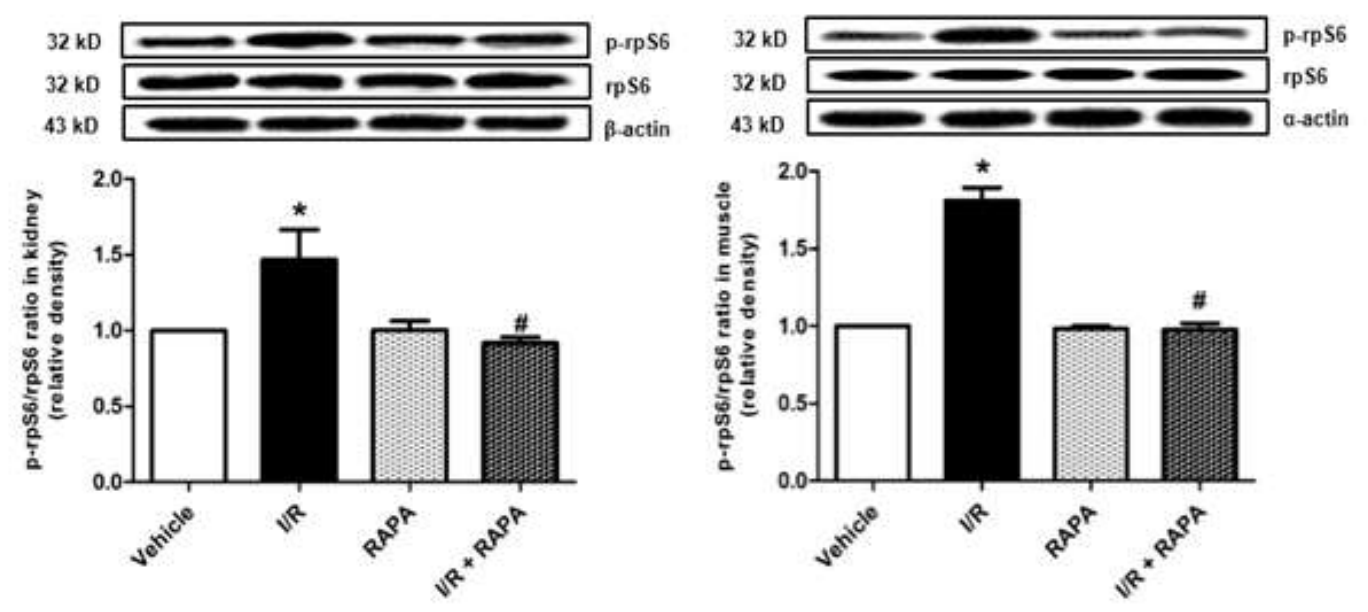

Figure 1. The effect of rapamycin on changes in ribosomal protein S6 (rpS6) expression and phosphorylation in the A kidney, B gastrocnemius muscle of rats measured at $8 \mathrm{~h}$ ischemia/reperfusion (I/R).

Rapamycin $(1 \mathrm{mg} / \mathrm{kg}$, i.p.) was given $1 \mathrm{~h}$ before reperfusion. rpS6 expression and phosphorylation in the tissue homogenates were detected by western blot assay. The density of bands was analyzed using Image J 1.42 software. Values are presented as the means \pm standard error mean $(\mathrm{n}=4)$. $* \mathrm{P}<0.05$ vs vehicle group; ${ }^{\# \mathrm{P}<0.05}$ vs I/R groups. I/R, RAPA, rapamycin. 
To evaluate whether MEK1/ERK1/2 was involved in $\mathrm{HL} \mathrm{I/R}$ injury, we measured the expression and phosphorylation of MEK1 and ERK1/2 in the gastrocnemius muscle and kidney of rats. While MEK1 and ERK1/2 protein expression were not changed, phosphorylation of these kinases was increased by HL I/R. Treatment with rapamycin reversed all these effects produced by $\mathrm{HL}$ $\mathrm{I} / \mathrm{R}(\mathrm{P}<0.05$; Fig. 2). Rapamycin alone did not alter the basal expression or phosphorylation of MEK1 and ERK1/2 in any of the tissues ( $\mathrm{P}>0.05$; Fig. 2$)$.
A
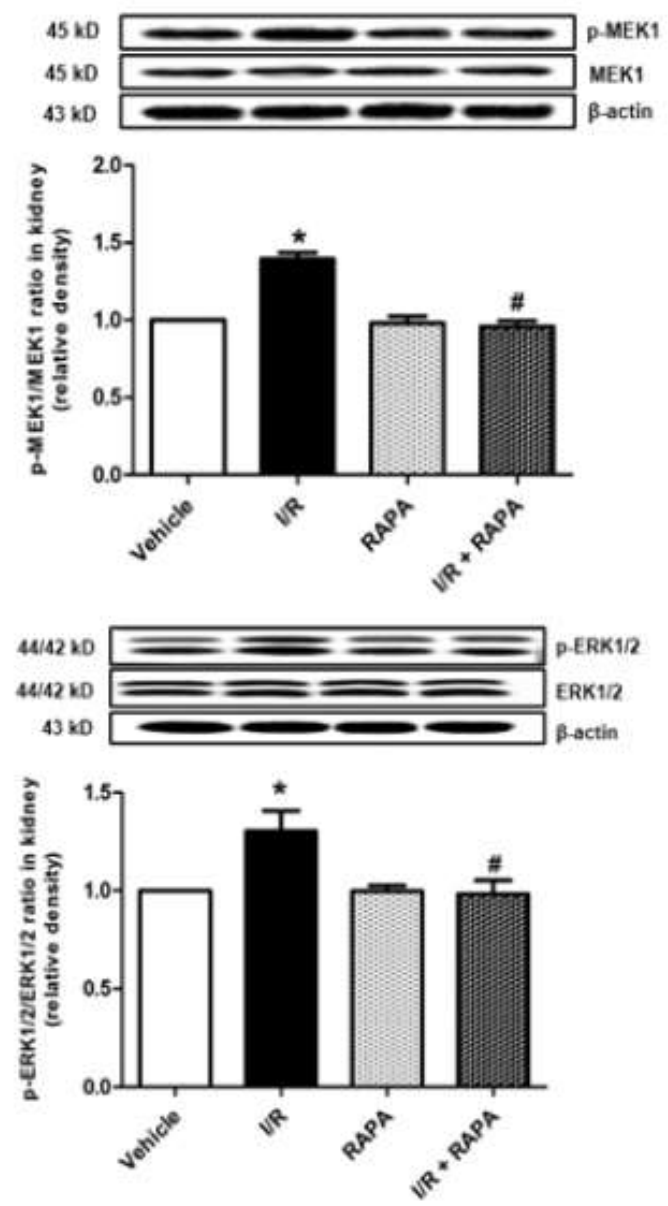

B
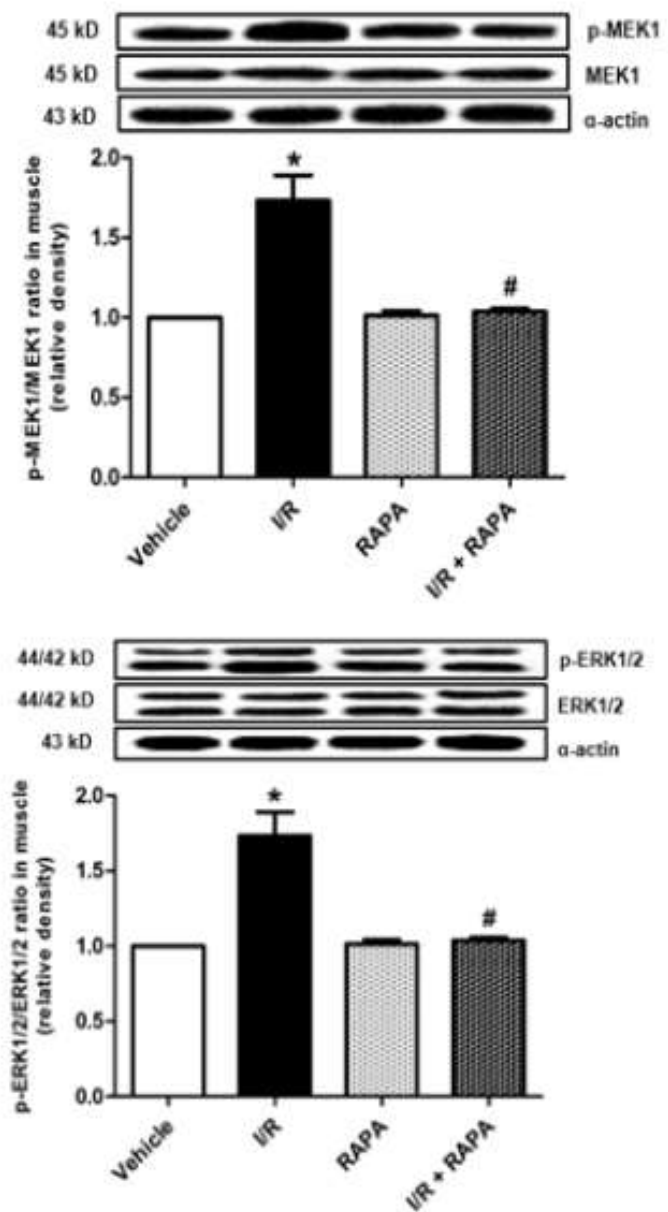

Figure 2. The effect of rapamycin on changes in mitogen-activated protein kinase kinase (MEK)1 and extracellular signal-regulated kinase (ERK) $1 / 2$ expression and phosphorylation in the A kidney, B gastrocnemius muscle of rats measured at $8 \mathrm{~h}$ ischemia/reperfusion (I/R).

Rapamycin (1 mg/kg, i.p.) was given $1 \mathrm{~h}$ before reperfusion. MEK1 and ERK1/2 expression and phosphorylation in the tissue homogenates were detected by western blot assay. The density of bands was analyzed using Image J 1.42 software. Values are presented as the means \pm standard error mean $(\mathrm{n}=4)$. ${ }^{*} \mathrm{P}<0.05$ vs vehicle group; ${ }^{\sharp} \mathrm{P}<0.05$ vs $\mathrm{I} / \mathrm{R}$ groups. 
A
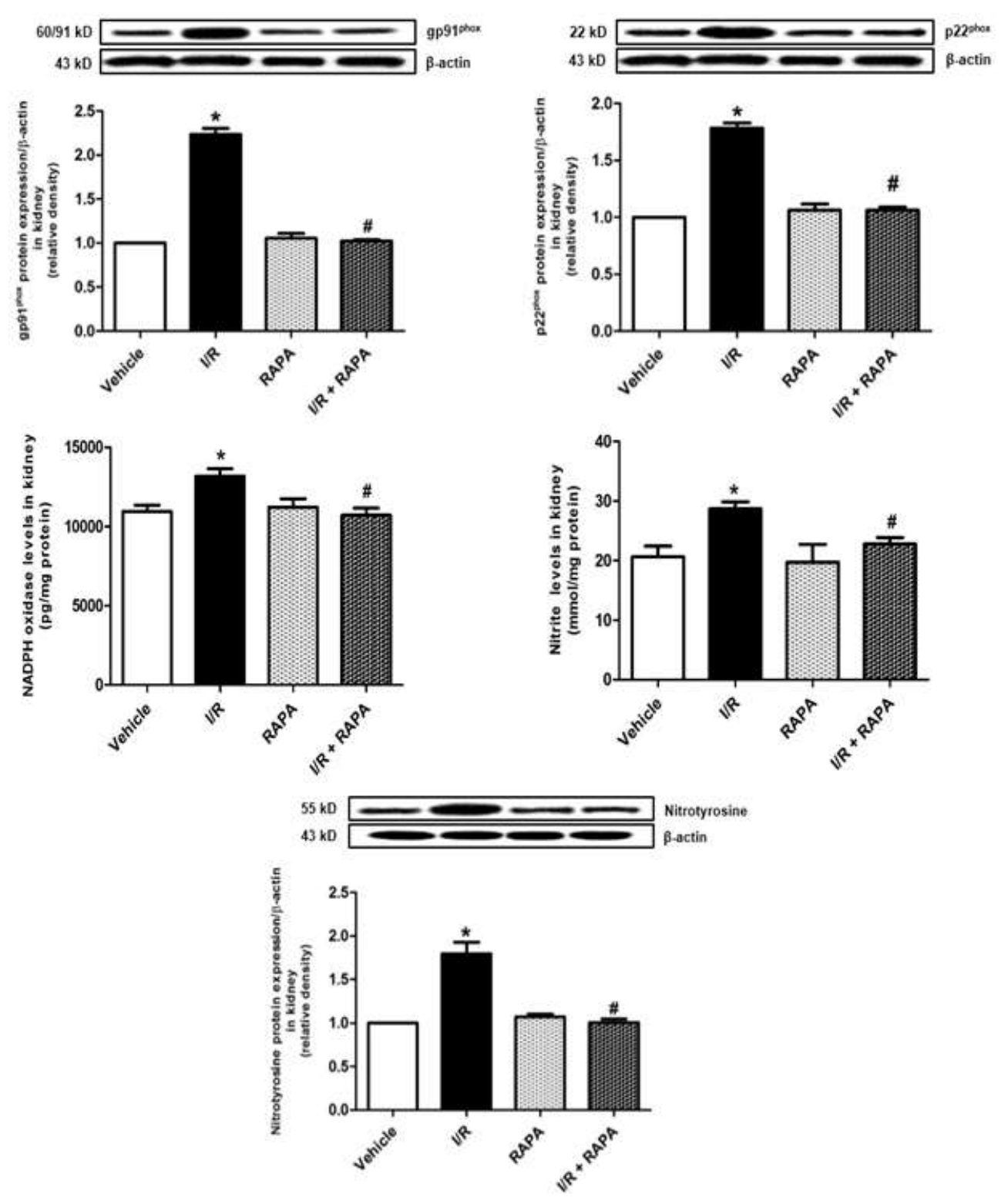
B
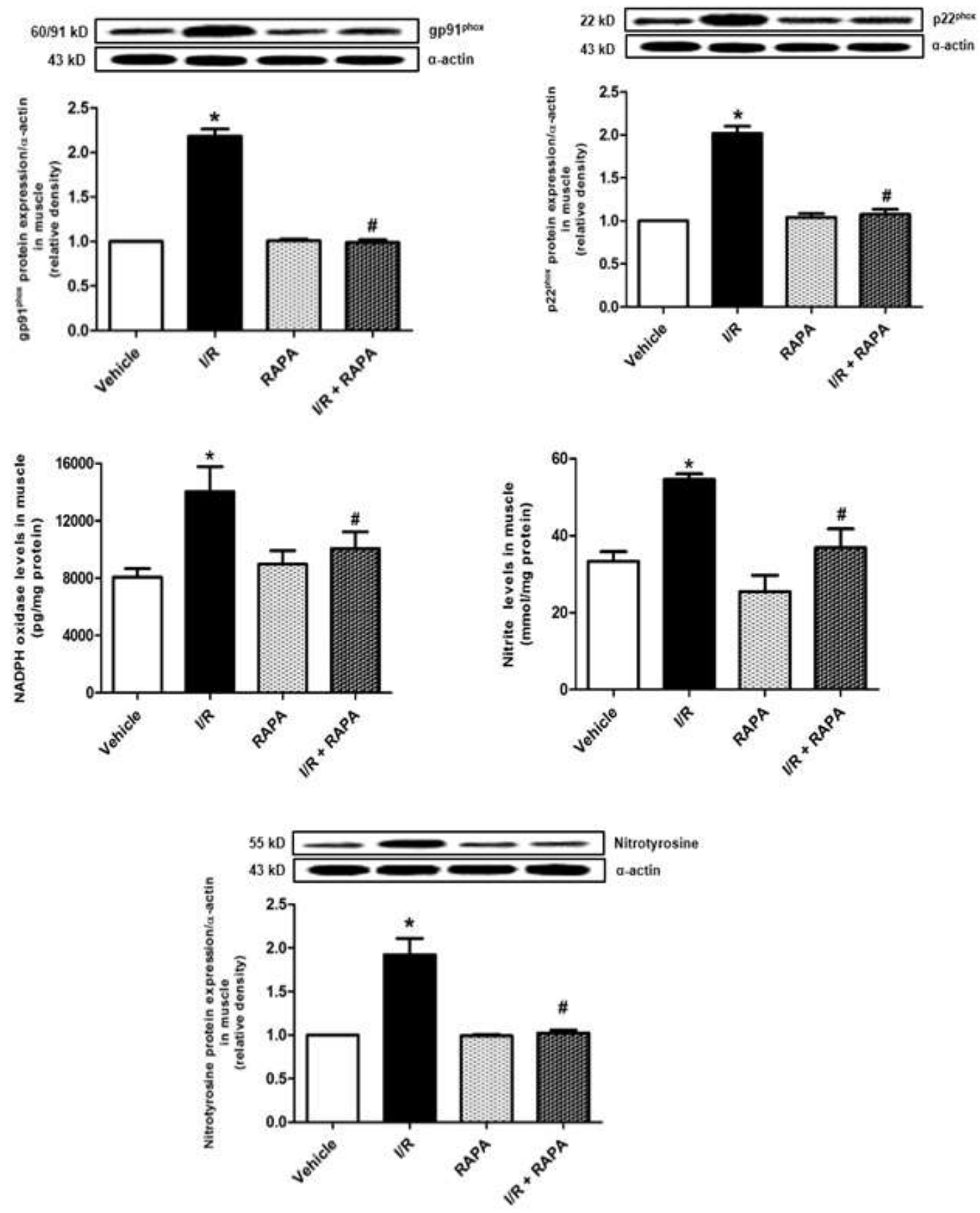
C

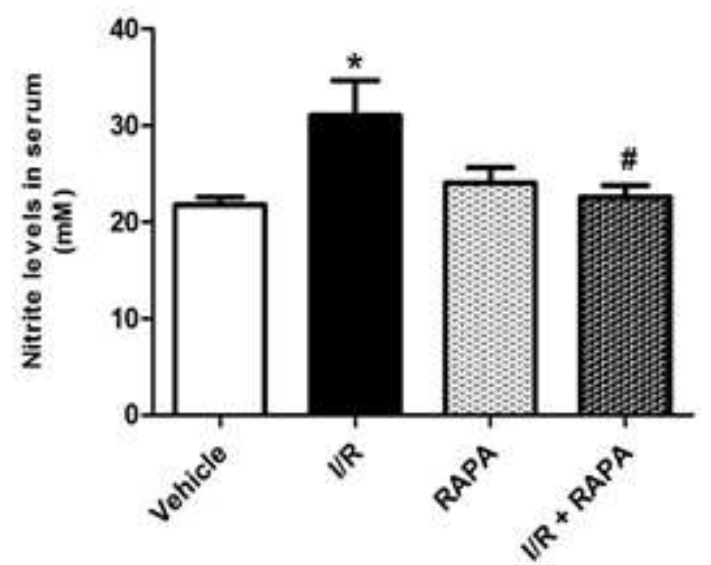

Figure 3 The effect of rapamycin on changes in expression of gp91phox, p22phox, nitrotyrosine and levels of nicotinamide adenine dinucleotide phosphate (NADPH) oxidase and nitrite in the A kidney, B gastrocnemius muscle and/or $C$ serum of rats measured at $8 \mathrm{~h}$ ischemia/reperfusion (I/R).

Rapamycin ( $1 \mathrm{mg} / \mathrm{kg}$, i.p.) was given $1 \mathrm{~h}$ before reperfusion. gp 91 phox , $22^{\text {phox }}$, and nitrotyrosine expression in the tissue homogenates were detected by western blot assay. The density of bands was analyzed using Image J 1.42 software. NADPH oxidase and nitrite levels in tissue homogenates and/or serum of rats were measured by ELISA kit and Griess reaction, respectively. Values are presented as the means \pm standard error mean $(\mathrm{n}=4-8) .{ }^{*} \mathrm{P}<0.05$ vs vehicle group; ${ }^{*} \mathrm{P}<0.05$ vs I/R groups. I/ $\mathrm{R}$, ischemia/reperfusion; RAPA, rapamycin.

To investigate the oxidative/nitrosative stress markers in HL I/R-induced muscle and kidney injury, we evaluated the $\mathrm{p} 22^{\mathrm{phox}}, \mathrm{gp} 91$ phox , and nitrotyrosine expression, NADPH oxidase, and nitrite levels in both tissues and serum. p22phox, gp91phox, nitrotyrosine expressions, and NADPH oxidase and nitrite levels, were significantly upregulated in response to $\mathrm{HL} \mathrm{I} / \mathrm{R}$ injury. In contrast, rapamycin markedly downregulated the activation of these oxidative/nitrosative stress parameters induced by HL I/R injury $(\mathrm{P}<0.05$; Fig. 3). Rapamycin alone did not affect protein expression or levels of any of these parameters in the tissues ( $\mathrm{P}>0.05$; Fig. 3$)$.

As displayed in Fig. 4, TNF- $\alpha$ and iNOS protein expression were significantly higher in the HL I/R group than in the vehicle group. However, rapamycin treatment inhibited TNF- $\alpha$ and iNOS protein expression in both muscle and kidney relative to the HL I/R group $(\mathrm{P}<0.05$; Fig. 4). Rapamycin did not alter the basal TNF- $\alpha$ and iNOS protein expression in any tissues ( $\mathrm{P}>0.05$; Fig. 4).

To evaluate MPO activity as a biochemical marker of neutrophil infiltration, we measured the levels of this enzyme in both muscle and kidney. MPO levels in these tissues were higher in the HL I/R group than those in the vehicle group. Treatment with rapamycin reduced HL I/R-induced MPO levels in both tissues $(\mathrm{P}<0.05$; Fig. 4). Rapamycin, given alone, did not affect MPO levels in any of the tissues $(\mathrm{P}>0.05$; Fig. 4). 
A
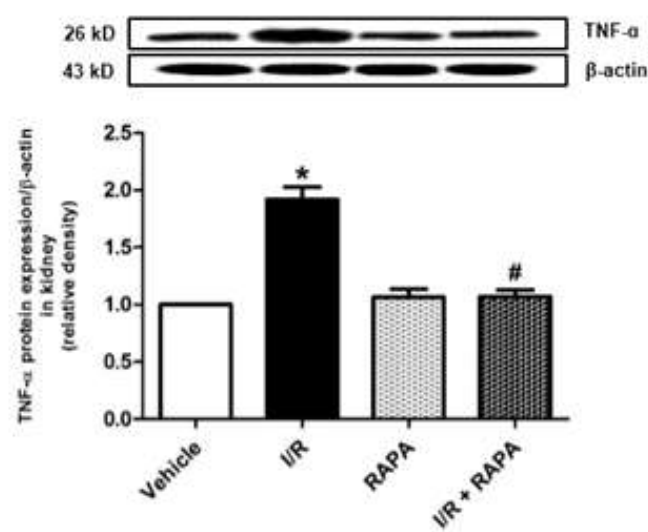

$130 \mathrm{kD}$ $43 \mathrm{kD}$
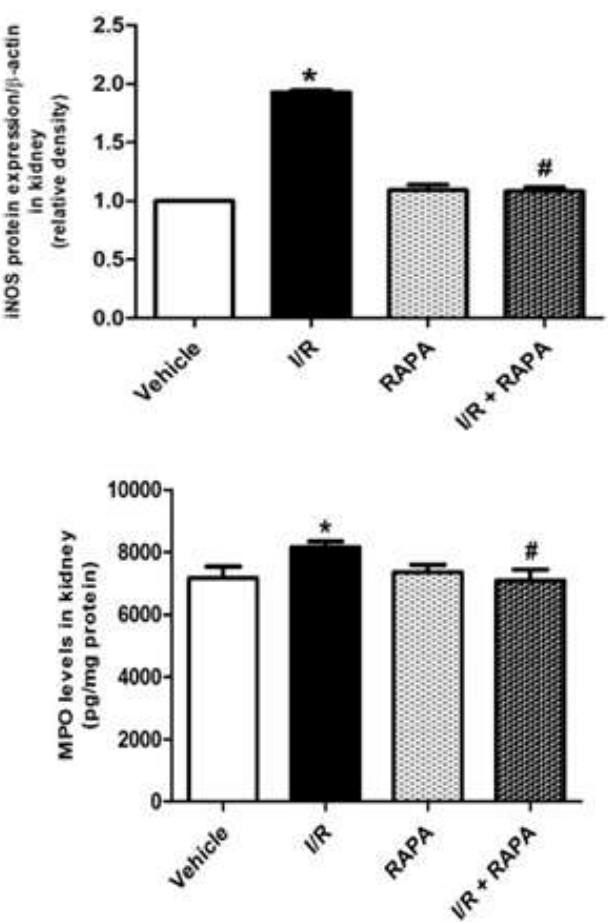

B
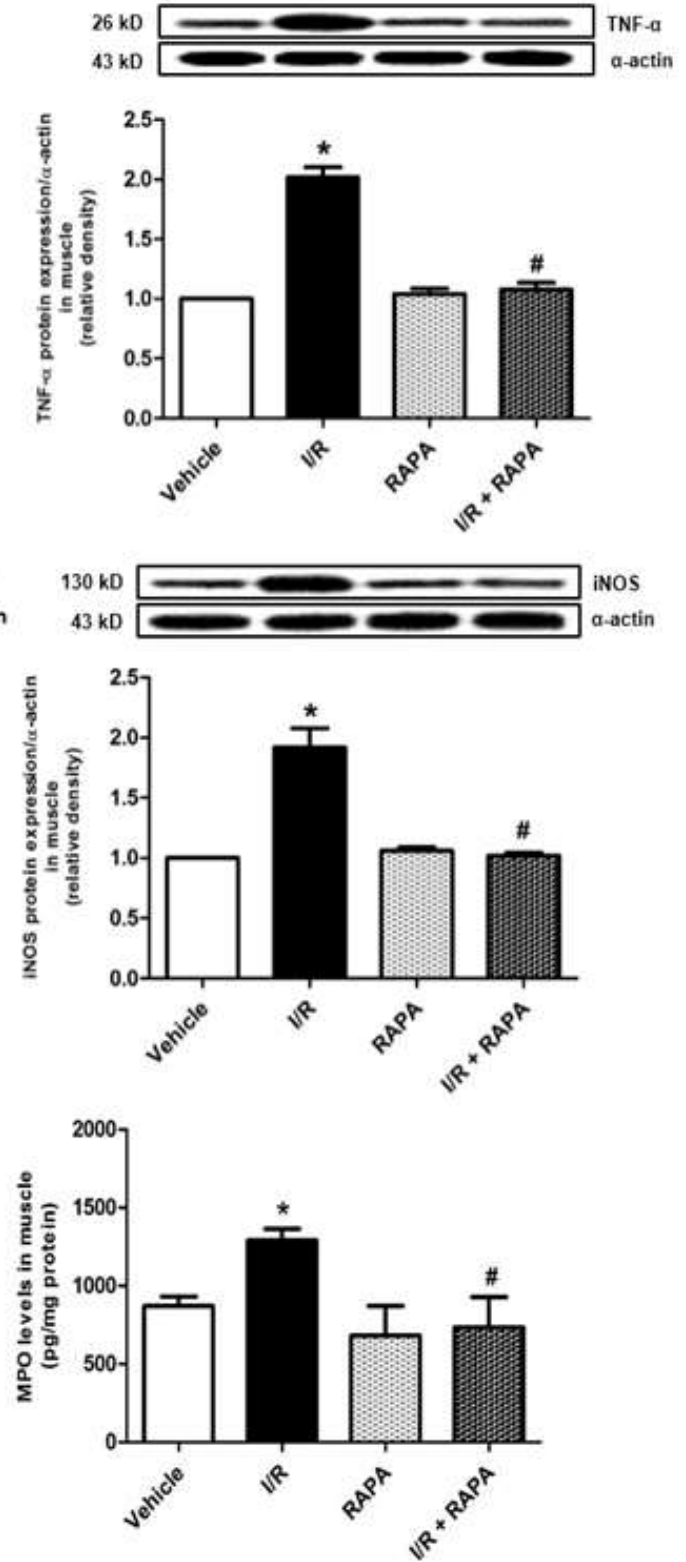

Figure 4 The effect of rapamycin on changes in expression of tumor necrosis factor (TNF)- $\alpha$ and inducible nitric oxide synthase (iNOS) as well as level of myeloperoxidase (MPO) in the A kidney, B gastrocnemius muscle of rats measured at $8 \mathrm{~h}$ ischemia/reperfusion (I/R).

Rapamycin $(1 \mathrm{mg} / \mathrm{kg}$, i.p.) was given $1 \mathrm{~h}$ before reperfusion. TNF- $\alpha$ and iNOS expression in the tissue homogenates were detected by western blot assay. Density of bands was analyzed using Image J 1.42 software. MPO level in tissue homogenates of rats was measured by ELISA kit. Values are presented as the means \pm Standard error mean $(\mathrm{n}=4-8)$. ${ }^{*} \mathrm{P}<0.05$ vs vehicle group; ${ }^{\#} \mathrm{P}<0.05$ vs I/R groups. 


\section{DISCUSSION}

Previously, we examined whether mTOR has a protective or deleterious role during $\mathrm{HL}$ I/R injury and provided the first evidence that mTOR contributes to inflammatory response and oxidative/nitrosative stress in both target and remote organs injuries in the murine model ${ }^{23}$. In the current study, we examined further looked out the molecular mechanism involved in the contribution of mTOR in HL I/R-induced organ injuries related to MEK1/ERK1/2. Our focus on mTOR-mediated MEK1/ERK1/2 signaling in the present study was supported by the evidence that inhibition of mTOR by rapamycin inhibited the expression and/or phosphorylation of MEK1, ERK1/2, nitrotyrosine and NADPH oxidase activity, and the expression of TNF- $\alpha$ and iNOS, and MPO activity.

The underlying mechanism responsible for HL I/Rassociated organ injuries is multifactorial and involves many signaling pathways and biological processes ${ }^{31}$. Among these signaling pathways, mTOR signaling has gained much attention. In the present study, the evidence that mTOR inhibitor rapamycin prevents the harmful effects of HL I/R in rats in both target and remote organs supports mTOR's critical role. This observation is consistent with the results of our previous studies and other researchers' findings that report the increment in the activity of mTOR signaling in in vitro and in vivo $\mathrm{HL} \mathrm{I} / \mathrm{R}$ injuries ${ }^{19}, 23,32$. However, the role of $\mathrm{mTOR}$ activation in HL I/R remains controversial. Although several investigators have suggested that mTOR activation exerts protective effects in $\mathrm{I} / \mathrm{R}$ injury, few studies have shown the deleterious role of mTOR in $\mathrm{I} / \mathrm{R}$ injury. Previous studies have shown that the mTOR pathway's downregulation after ischemia is caused by a low cellular energy state, most likely during the ischemic period ${ }^{33-35}$. However, recently an early activation of mTOR was reflected by increased levels of phosphorylated mTOR, P70S6K, and rpS6 proteins after transient forebrain ischemia ${ }^{36}$. This was followed by the study of Crozier et al., who have reported elevated activity of $\mathrm{PI} 3 \mathrm{~K} / \mathrm{Akt} / \mathrm{mTOR}$ signaling in cardiac $\mathrm{I} / \mathrm{R}$ injury ${ }^{32}$. Moreover, the deletion of $\mathrm{mTORC} 1$ protects against HL I/R injury, most probably via attenuation of oxidative stress and alleviation of inflammation in mice ${ }^{37}$. The contradictory effects of mTOR might be interpreted as the differences in the observation time points or experimental ischemia models, which needs further investigation.
Most importantly, in our study, we focused on the elucidation of the possible molecules mediating the harmful effects of $\mathrm{mTOR}$, and we aimed to characterize the precise roles of MEK1 and ERK1/2 in the molecular basis of the possible mechanism to ascertain how mTOR affects the HL I/R-related organ injuries. MAPKs, one of the main pathways underlying inflammation and oxidative/nitrosative stress, cause organ damage ${ }^{38,39}$. It was recently shown that MAPKs being activated by MEK1 might exaggerate inflammation and ROS formation, leading to necrosis ${ }^{40-42}$. However, in vivo evidence on the strategies on directly blocking MAPK activation in the pathophysiological process of HL I/R is not thoroughly evaluated. That's why, ERK's virtue in ischemic models is highly debatable, and it has been shown to be involved in both protection and exacerbation of ischemic injury, especially in the brain. We reported here that the activation of MEK1/ERK1/2 pathway is increased, as reflected by increased levels of $\mathrm{p}-\mathrm{MEK} 1$ and $\mathrm{p}-\mathrm{ERK} 1 / 2$ proteins in HL I/R in the muscle and kidney, and that rapamycin treatment was significantly reduced their phosphorylation. A similar report from Sari et al. showed that MEK1/ERK1/2 activation is involved in organ injury in the HL I/R model ${ }^{24}$. These results, showing dramatic changes in $\mathrm{p}-\mathrm{MEK} 1$ and $\mathrm{p}$ ERK1/2 proteins after reperfusion following ischemia, strongly indicate that MEK1/ERK1/2 signaling plays a role in cell response to $\mathrm{HL} I / \mathrm{R}$ injury. Along with these, there is also substantial evidence in the literature that supports these results. It has been demonstrated that the selective MEK inhibitor U0126 reduces ischemic injury by blocking increases in $\mathrm{p}-\mathrm{MEK} 1$ and $\mathrm{p}$-ERK1/2 proteins, suggesting a detrimental role for MEK1/ERK1/2 pathway. Similarly, other MEK inhibitors, PD98059 and SL327, reduced infarction after stroke and improved cell survival by attenuating MEK1 and ERK1/2 phosphorylation ${ }^{43}$, ${ }^{44}$. Besides the observations mentioned above, the salient findings from the present study indicated that inhibition of mTOR decreases HL I/R-induced organ damage in muscle and kidney, potentially by suppressing MEK1/ERK1/2 activity.

In general, HL I/R injuries are caused by increased oxidative stress, intracellular and mitochondrial $\mathrm{Ca}^{2+}$ overload, and inflammation involving neutrophil infiltration to the target or remote organs with a subsequent release of ROS and degradative enzymes $^{45}$. It is well established that the overproduction of ROS is another one of the most 
crucial mechanisms underlying the damaging effects of $\mathrm{HL} \mathrm{I} / \mathrm{R}$ induing vital organ injuries as the HL I/Rinduced burst of ROS could imbalance the cellular redox condition and interfere with the vital pathways involved in cellular survival, including energy metabolism and apoptosis ${ }^{3,} 4,46$. ROS and peroxynitrite cause cellular injury and necrosis via distinct mechanisms, including peroxidation of membrane lipids, protein denaturation, and activation of several kinases. Since it is well known that increased ROS production is correlated with elevated ERK1/2 activation, it is possible that ROSstimulated ERK1/2 activation might facilitate ischemic injury ${ }^{47}$. Additionally, the continuous increase in ROS not only increases the level of $\mathrm{p}$ ERK1/2 protein but also extends the active time abnormally, suggesting a possible close relationship between ERK1/2 and ROS formation. Therefore, we investigated the role of $\mathrm{mTOR}$ inhibition on MEK1/ERK1/2 activity in the regulation of oxidative stress to provide mechanistic insights into the role of $\mathrm{mTOR}$ in the $\mathrm{HL} \mathrm{I/R}$ injury. In the current study, inhibition of mTOR attenuated HL I/R-elicited gp91phox and p22phox as well as NADPH oxidase activity in the muscle and kidney. Moreover, increased nitrotyrosine expression, as an indicator of peroxynitrite formation, was reversed by rapamycin in $\mathrm{HL} I / \mathrm{R}$ in the rat. In parallel to our results, inhibition of mTORC1 either with rapamycin or by S6K1 silencing recouples endothelial NOS function, improves $\mathrm{NO}$ production, and inhibits $\mathrm{O}_{2}-$ generation in the rat aortas in the models of postmyocardial infarction, another ischemic disease ${ }^{48}$. Also, it is noteworthy that mTOR promotes oxidative metabolism through mitochondrial biogenesis and increases NADPH oxidase activity ${ }^{49}$. In another study, it has also been reported that mTOR activation can induce NADPH oxidase activity and cytosolic ROS formation. At the same time, inhibition of cytosolic ROS through NADPH oxidase inhibition could also block mTOR phosphorylation, suggesting a positive feedback loop between mTOR activation with ROS formation. mTOR inhibition could also prevent mitochondrial ROS formation, and scavenging of mitochondrial ROS inhibits increased inflammatory response ${ }^{50}$. Judging from these data, we further speculate that inhibition of mTOR attenuates HL I/R-induced organ injuries via suppressing oxidative/nitrosative stress markers.

Although the mechanisms of skeletal muscle I/R injuries are complicated, increasing evidence suggests that inflammatory events play a crucial role in the pathogenesis of muscle and kidney injury in HL $\mathrm{I} / \mathrm{R}^{51,52}$. In the background of the evolving target and remote organ complications following $\mathrm{HL} \mathrm{I/R,} \mathrm{the}$ generalization of the local inflammatory process has an important effect ${ }^{53}$. To address this, in the current study, we observed significant increases in TNF- $\alpha$ and iNOS expression as well as MPO activity in muscle and kidney after HL I/R, which were reduced by rapamycin. This observation supports the view that HL I/R-induced severe inflammatory responses are relieved via inhibition of mTOR activity. Growing evidence has illustrated that the levels of proinflammatory cytokines $\mathrm{TNF}-\alpha$, interleukin (IL)$1 \beta$, and IL- 6 are elevated in HL I/R, indicating the vital role of inflammation in HL I/R injury ${ }^{54}$. There is also a close interaction between inflammatory events and MEK1/ERK1/2 activity in HL I/R injury. ERK1/2 transactivates transcription factors such as NF- $x \mathrm{~B}$ and AP-1 binding to the promoters of many mediators of inflammation, including cytokines and matrix metalloproteases, upregulating the expression of these inflammatory mediators ${ }^{55}$. Moreover, previous studies have shown that the expression of activated ERK1/2 and p38 MAPK may play a key role in the production of inflammatory cytokines and free radicals ${ }^{56,57}$. That's why blockade of MAPKs has been implicated in attenuating various diseases significantly associated with inflammation. On the other hand, the expression of inflammation triggered by ROS, which also generates ROS and inflammatory cytokines, could further augment HL $\mathrm{I} / \mathrm{R}$ injury ${ }^{58,59}$. In the light of the findings of this study, the mechanism underlying the effects of mTOR mediating HL I/R injury may be explained by triggering the inflammatory events via increased MEK1/ERK1/2 activity and the anti-inflammatory effect of rapamycin to attenuate the activity of these MAPKs and muscle and kidney injury in HL I/R in rats.

In conclusion, increasing lines of evidence show that exacerbated oxidative stress and inflammatory events participate in skeletal muscle and kidney damage in $\mathrm{HL} I / \mathrm{R}$, despite the signaling pathways involved remain largely unclear. Our study demonstrates that the MEK1/ERK1/2 signaling pathway might serve to understand the molecular mechanisms of the role of mTOR involved in organ damage after ischemic challenge. In keeping with our and other researchers' results, it was suggested that mTOR and MEK1/ERK1/2, which have effects on oxidative stress and inflammatory responses, are attractive therapeutic targets for ischemic diseases. However, 
because of this study's limitation on the absence of the immunohistological evaluation for the demonstration of tissue injury, further studies are needed to elucidate the mechanism of the pathological events and the organ damage underlying HL I/R and its relationship to mTOR.

Yazar Katkıları: Calışma konsepti/Tasarımı: CAU, MTR, SSF; Veri toplama: CAU, MTR, DSG, SPS, OV, NS, SSF; Veri analizi ve yorumlama: CAU, MTR, SSF; Yazı taslağı: MTR, SSF; İçeriğin elestirel incelenmesi: DSG, SPS, OV, NS, BT; Son onay ve sorumluluk:SSF; Teknik ve malzeme desteği: -; Süpervizyon: KUM; Fon sağlama (mevcu ise): yok.

Etik Onay: Deneysel protokol, Mersin Üniversitesi Deney Hayvanlar Yerel Etik Kurulu tarafindan 26/02/2018 tarih ve 2018/08 sayll karat ile onaylanmıştır.

Hakem Değerlendirmesi: Dış bağımsız.

Çıkar Çatışması: Yazarlar çıkar çatıșması olmadığını beyan ederler.

Finansal Destek: Bu çalışma Türkiye'de Mersin Üniversitesi Araştırma Vakfi tarafindan desteklendi [Proje Numarasi: 2018-2-TP2-2984].

Yazarın Notu: Bu çalışmanın sonuçları Pharm.M. S. Çağla AkıncıUysal Yüksek Lisans Tezi'nde yerleştirilmiştir.

Author Contributions: Concept/Design : CAU, MTR, SSF; Data acquisition: CAU, MTR, DSG, SPS, OV, NS, SSF; Data analysis and interpretation: CAU, MTR, SSF; Drafting manuscript: MTR, SSF Critical revision of manuscript: DSG, SPS, OV, NS, BT; Final approval and accountability: SSF; Technical or material support: -; Supervision: KUM; Securing funding (if available): $\mathrm{n} / \mathrm{a}$.

Ethical Approval: The experimental protocol was approved by the Mersin University Experimental Animals Local Ethics Committee with the decision dated 26/02/2018 and numbered 2018/08.

Peer-review: Externally peer-reviewed.

Conflict of Interest: The authors declare that they have no conflict of interest.

Financial Disclosure: This work was supported by the Research Foundation of Mersin University in Turkey [Project Number: 2018-2TP2-2984].

Acknowledgement: The results of this study were included in the Master's Thesis of Pharm. M. S. Cagla Akinci-Uysal.

\section{REFERENCES}

1. Land WG. The role of postischemic reperfusion injury and other nonantigen-dependent inflammatory pathways in transplantation. Transplantation. 2005;79:505-14.

2. Grace PA. Ischaemia-reperfusion injury. Br J Surg. 1994;81:637-47.

3. Yassin MM, Harkin DW, Barros D'Sa AA, Halliday MI, Rowlands BJ. Lower limb ischemiaereperfusion injury triggers a systemic inflammatory response and multiple organ dysfunction. World J Surg. 2002;26:115-21.

4. Tassiopoulos AK, Carlin RE, Gao Y, Pedoto A, Finck CM, Landas SK et al. Role of nitric oxide and tumor necrosis factor on lung injury caused by ischemia/reperfusion of the lower extremities. J Vasc Surg. 1997;26:647-56

5. Blaisdell FW. The pathophysiology of skeletal muscle ischemia and the reperfusion syndrome: a review. Cardiovasc Surg. 2002;10:620-30.
6. Acar RD, Sahin M, Kirma C. One of the most urgent vascular circumstances: Acute limb ischemia. SAGE Open Med. 2013;1:2050312113516110.

7. Volanska M, Zavacky P, Bober J. Ischaemicreperfusion damage of tissue and critical limb ischaemia. Bratisl Lek Listy. 2006;107:264-8.

8. Takhtfooladi MA, Jahanshahi G, Jahanshahi A, Sotoudeh A, Samiee Amlashi O, Allahverdi A. Effects of $\mathrm{N}$-acetylcysteine on liver remote injury after skeletal muscle ischemia reperfusion in rats. Turk J Gastroenterol. 2014;25:43-7.

9. Takhtfooladi MA, Jahanshahi A, Sotoudeh A, Jahanshahi G, Takhtfooladi HA, Aslani K. Effect of tramadol on lung injury induced by skeletal muscle ischemia reperfusion: an experimental study. J Bras Pneumol. 2013;39:434-9.

10. Takhtfooladi MA, Takhtfooladi HA, Moayer F, Karimi P, Asl HA. Effect of Otostegia persica extraction on renal injury induced by hindlimb ischemia-reperfusion: a rat model. Int J Surg. 2015;13:124-30.

11. Takhtfooladi MA, Jahanshahi A, Sotoudeh A, Daneshi MH, Khansari M, Takhtfooladi HA. The antioxidant role of $\mathrm{N}$-acetylcysteine on the testicular remote injury after skeletal muscle ischemia and reperfusion in rats. Pol J Pathol. 2013;64:204-9.

12. Emrecan B, Tulukoglu E, Bozok S, Kestelli M, Onem G, Küpelioglu A et al. Effects of iloprost and pentoxifylline on renal ischemia-reperfusion in rabbit model. Eur J Med Res. 2006;11:295-9.

13. Gradl G, Gaida S, Finke B, Lindenblatt N, Gierer P, Menger MD et al. Supernatant of traumatized muscle induces inflammation and pain, but not microcirculatory perfusion failure and apoptotic cell death. Shock. 2005;24:219-25.

14. Hsu KY, Chen C, Shih P, Huang C. Adverse effects of bilateral lower limb ischemiaereperfusion on inducing kidney injuries in rats could be ameliorated by platonin. Acta Anaesthesiol Taiwan. 2012;50:63-8.

15. Li X, Ren C, Li S, Han R, Gao J, Huang Q et al. Limb remote ischemic conditioning promotes myelination by upregulating PTEN/Akt/ mTOR signaling activities after chronic cerebral hypoperfusion. Aging Dis. 2017;8:392-401.

16. Javedan G, Shidfar F, Davoodi SH, Ajami M, Gorjipour F, Sureda A et al. Conjugated linoleic acid rat pretreatment reduces renal damage in ischemia/reperfusion injury: Unraveling antiapoptotic mechanisms and regulation of phosphorylated mammalian target of rapamycin. Mol Nutr Food Res. 2016;60:2665-77.

17. Pazoki-Toroudi $H$, Nilforoushzadeh MA, Ajami M, Jaffary F, Aboutaleb N, Nassiri-Kashani M et al. Combination of azelaic acid 5\% and clindamycin 2\% for the treatment of acne vulgaris. Cutan Ocul Toxicol. 2011;30:286-91.

18. Chen HC, Fong TH, Hsu PW, Chiu WT. Multifaceted effects of rapamycin on functional recovery after 
spinal cord injury in rats through autophagy promotion, anti-inflammation and neuroprotection. J Surg Res. 2013;179:203-10.

19. Fletcher L, Evans TM, Watts LT, Jimenez DF, Digicaylioglu M. Rapamycin treatment improves neuron viability in an in vitro model of stroke. PLoS One. 2013;8:e68281.

20. Liang D, Han D, Fan W, Zhang R, Qiao H, Fan M et al. Therapeutic efficacy of apelin on transplanted mesenchymal stem cells in hindlimb ischemic mice via regulation of autophagy. Sci Rep. 2016;6:21914.

21. Zhao D, Yang J. Insights for oxidative stress and mTOR signaling in myocardial ischemia/reperfusion injury under diabetes. Oxid Med Cell Longev. 2017;6437467.

22. Wei H, Li Y, Han S, Liu S, Zhang N, Zhao L et al. cPKCgamma-modulated autophagy in neurons alleviates ischemic injury in brain of mice with ischemic stroke through Akt-mTOR pathway. Transl Stroke Res. 2016;7:497-511.

23. Kocak Z, Temiz-Resitoglu M, Guden DS, Vezir O, Sucu N, Balc1 S et al. Modulation of oxidativenitrosative stress and inflammatory response by rapamycin in target and distant organs in rats exposed to hindlimb ischemia-reperfusion: the role of mammalian target of rapamycin. Can J Physiol Pharmacol. 2019;97:1193-203.

24. Sari AN, Kacan M, Unsal D, Sahan-Firat S, Buharalioglu CK, Vezir O et al. Contribution of RhoA/Rho-kinase/MEK1/ERK1/2/iNOS pathway to ischemia/reperfusion-induced oxidative/nitrosative stress and inflammation leading to distant and target organ injury in rats. Eur J Pharmacol. 2014:723:234-45.

25. Sucu N, Unlu A, Tamer L, Aytacoğlu B, Coskun B, Bilgin $\mathrm{R}$ et al. Effects of trimetazidine on tissue damage in kidney after hindlimb ischemiareperfusion. Pharmacol Res. 2002;46:345-9.

26. Temiz-Resitoglu M, Kucukkavruk SP, Guden DS, Cecen P, Sari AN, Tunctan B et al. Activation of mTOR/I $x \mathrm{~B}-\alpha / \mathrm{NF}-x \mathrm{~B}$ pathway contributes to LPSinduced hypotension and inflammation in rats. Eur J Pharmacol. 2017;802:7-19.

27. Tunctan B, Korkmaz B, Sari AN, Kacan M, Unsal D, Serin MS et al. Contribution of iNOS/sGC/PKG pathway, COX-2, CYP4A1, and gp91phox to The protective effect of 5,14-HEDGE, a20-HETE mimetic, against vasodilation, hypotension, tachycardia, and inflammation in a rat model of septic shock. Nitric Oxide. 2013a;33:18-41.

28. Tunctan B, Korkmaz B, Sari AN, Kacan M, Unsal D, Serin MS et al. 5,14-HEDGE, a 20-HETE mimetic, reverses hypotension and improves survival in a rodent model of septic shock: contribution of soluble epoxide hydrolase, $\quad$ CYP2C23, MEK1/ERK1/2/IKK $\beta / \mathrm{I} \varkappa \mathrm{B}-\alpha / \mathrm{NF}-\varkappa \mathrm{B}$ pathway, and proinflammatory cytokine formation. Prostaglandins Other Lipid Mediat. 2013b;102-103:31-41.
29. Sahan-Firat S, Temiz-Resitoglu M, Guden DS, Kucukkavruk SP, Tunctan B, Sari AN et al. Protection by mTOR inhibition on zymosan-induced systemic inflammatory response and oxidative/nitrosative stress: Contribution of mTOR/MEK1/ERK1/2/IKK $\beta /$ I $x$ B $-\alpha / N F-x$ B signalling pathway. Inflammation. 2018;41:276-98.

30. Green LC, Wagner DA, Glogowski J, Skipper PL, Wishnok JS, Tannenbaum SR. Analysis of nitrate, nitrite, and $[15 \mathrm{~N}]$ nitrate in biological fluids. Anal Biochem. 1982;126:131-8.

31. Raedschelders K, Ansley DM, Chen DD. The cellular and molecular origin of reactive oxygen species generation during myocardial ischemia and reperfusion. Pharmacol Ther. 2012;133:230-55.

32. Crozier SJ, Zhang X, Wang J, Cheung J, Kimball SR, Jefferson LS. Activation of signaling pathways and regulatory mechanisms of mRNA translation following myocardial ischemia-reperfusion. J Appl Physiol. 2006;101:576-82.

33. Foster KG, Fingar DC. Mammalian target of rapamycin (mTOR): conducting the cellular signaling symphony. J Biol Chem. 2010;285:14071-7.

34. Sofer A, Lei K, Johannessen CM, Ellisen LW. Regulation of mTOR and cell growth in response to energy stress by REDD1. Mol Cell Biol. 2005;25:5834-45.

35. Koh PO. Gingko biloba extract (EGb 761) prevents cerebral ischemia-induced p70S6 kinase and S6 phosphorylation. Am J Chin Med. 2010;38:727-34.

36. Yang X, Hei C, Liu P, Song Y, Thomas T, Tshimanga $\mathrm{S}$ et al. Inhibition of mTOR pathway by rapamycin reduces brain damage in rats subjected to transient forebrain ischemia. Int J Biol Sci. 2015;11:1424-35.

37. Fan W, Han D, Sun Z, Ma S, Gao L, Chen J et al. Endothelial deletion of mTORC1 protects against hindlimb ischemia in diabetic mice via activation of autophagy, attenuation of oxidative stress and alleviation of inflammation. Free Radic Biol Med. 2017;108:725-40.

38. Roux PP, Blenis J. ERK and p38 MAPK-activated protein kinases: a family of protein kinases with diverse biological functions. Microbiol Mol Biol Rev. 2004;68:320-44.

39. Carletti R, Tacconi S, Bettini E, Ferraguiti F. Stress activated protein kinases, a novel family of mitogenactivated protein kinases are heterogeneously expressed in the adult rat brain and differentially disturbed extracellular-signal-regulated protein kinases. Neuroscience. 1995;69:1103-10.

40. Duan W, Chan JH, Wong CH, Leung BP, Wong WS. Anti-inflammatory effects of mitogen-activated protein kinase kinase inhibitor U0126 in an asthma mouse model. J Immunol. 2004;172:7053-9.

41. Lee PJ, Zhang X, Shan P, Ma B, Lee CG, Homer RJ. ERK1/2 mitogen-activated protein kinase selectively mediates IL-13-induced lung inflammation and remodeling in vivo. J Clin Invest. 2006;116:163-73. 
42. Wang ZQ, Wu DC, Huang FP, Yang GY. Inhibition of MEK/ERK $1 / 2$ pathway reduces proinflammatory cytokine interleukin-1 expression in focal cerebral ischemia. Brain Res. 2004;996:55-66.

43. Alessandrini A, Namura S, Moskowitz MA, Bonventre JV. MEK1 protein kinase inhibition protects against damage resulting from focal cerebral ischemia. Proc Natl Acad Sci USA. 1999;96:12866-9.

44. Namura S, Iihara K, Takami S, Nagata I, Kikuchi H, Matsushita $\mathrm{K}$ et al. Intravenous administration of MEK inhibitor U0126 affords brain protection against forebrain ischemia and focal cerebral ischemia. Proc Natl Acad Sci USA. 2001;98:11569-74.

45. Vinten-Johansen J. Involvement of neutrophils in the pathogenesis of lethal myocardial reperfusion injury. Cardiovasc Res. 2004;61:481-97.

46. Becker LB. New concepts in reactive oxygen species and cardiovascular reperfusion physiology. Cardiovasc Res. 2004;61:461-70.

47. Sawe N, Steinberg G, Zhao H. Dual roles of the MAPK/ERK1/2 cell signaling pathway after stroke. J Neurosci Res. 2008;86:1659-69.

48. Rajapakse AG, Yepuri G, Carvas JM, Stein S, Matter $\mathrm{CM}$, Scerri I et al. Hyperactive S6K1 mediates oxidative stress and endothelial dysfunction in aging: inhibition by resveratrol. PLoS ONE. 2011;6:e19237.

49. Cunningham JT, Rodgers JT, Arlow DH, Vazquez F, Mootha VK, Puigserver P. mTOR controls mitochondrial oxidative function through a YY1PGC-1 $\alpha$ transcriptional complex. Nature. 2007;450:736-40.

50. Sohrabi Y, Lagache SMM, Schnack L, Godfrey R, Kahles F, Bruemmer D et al. mTOR-dependent oxidative stress regulates oxLDL-induced trained Innate 1mmunity in human monocytes. Front Immunol. 2019;22:3155.
51. Hammers DW, Rybalko V, Merscham-Banda M, Hsieh PL, Suggs LJ, Farrar RP. Anti-inflammatory macrophages improve skeletal muscle recovery from ischemia-reperfusion. J Appl Physiol. 2015;118:106774.

52. Urso ML. Anti-inflammatory interventions and skeletal muscle injury: benefit or detriment? J Appl Physiol. 2013;115:920-8.

53. Ferrari RS, Andrade CF. Oxidative stress and lung ischemia-reperfusion injury. Oxid Med Cell Longev. 2015;590987.

54. Zheng T, Jiang H, Jin R, Zhao Y, Bai Y, Xu H et al. Ginsenoside Rg1 attenuates protein aggregation and inflammatory response following cerebral ischemia and reperfusion injury. Eur J Pharmacol. 2019;853:6573.

55. Foletta VC, Segal DH, Cohen DR. Transcriptional regulation in the immune system: all roads lead to AP1. J Leukoc Biol. 1998;63:139-52.

56. Choi SH, Joe EH, Kim SU, Jin BK. Thrombininduced microglial activation produces degeneration of nigral dopaminergic neurons in vivo. J Neurosci. 2003;23:5877-86

57. Combs CK, Karlo JC, Kao SC, Landreth GE. Betaamyloid stimulation of microglia and monocytes results in TNFalpha-dependent expression of inducible nitric oxide synthase and neuronal apoptosis. J Neurosci. 2001;21:1179-88.

58. Zu G, Guo J, Che N, Zhou T, Zhang X. Protective effects of ginsenoside $\operatorname{Rg} 1$ on intestinal ischemia/reperfusion injury-induced oxidative stress and apoptosis via activation of the $\mathrm{Wnt} / \beta$-catenin pathway. Sci Rep. 2016;6:38480.

59. Borges SC, da Silva de Souza AC, Beraldi EJ, Schneider LC, Buttow NC. Resveratrol promotes myenteric neuroprotection in the ileum of rats after ischemiareperfusion injury. Life Sci. 2016;166:54-9. 